\title{
Work Of Legal Products Traffic In Overcoming Road Conclusion
}

\author{
Fadli*) and Akhmad Khisni**) \\ *) Indonesian National Police; E-mail fadli.sh71@gmail.com \\ ${ }^{* *}$ Faculty of Law, Universitas Islam Sultan Agung (Unissula) Semarang
}

\begin{abstract}
The purpose of this study is to examine and analyze the concept of the substance of traffic law products in overcoming road congestion. This research uses a normative juridical method with research specifications in the form of descriptive analysis. Based on the discussion, it is concluded that the state's efforts in the form of legislation with the existence of legal products that are correlated with overcoming the problem of congestion on the highway with various concepts of interrelated substances include Act No. 22 of 2009, concerning traffic and transportation. Act No. 23 of 2014 concerning Regional Government in Article 9 paragraph (1) states that there are 3 (three) types of government affairs, namely absolute government affairs, concurrent government affairs, and general government affairs. Government affairs under the authority of the Regions consist of Mandatory Government Affairs and Preferred Government Affairs. Article 10 of Act No. 38 of 2004 concerning Roads states that to regulate road use and smooth traffic, roads are divided into several road classes. Government Regulation Number 32 of 2011 concerning Management and Engineering, Impact Analysis, and Traffic Needs Management, the scope of regulation of PP Management and Engineering, Impact Analysis, and Traffic Needs Management includes traffic management and engineering activities including planning, regulation, engineering, empowerment, and supervision.
\end{abstract}

Keywords:Law; Traffic; Highway Congestion.

\section{Introduction}

Indonesia is a state of law, the statement is contained in the Elucidation of the 1945 Constitution of the Republic of Indonesia stating that "the Indonesian state is based on law (rechtstaat) not based on mere power (machtstaat)", ${ }^{1}$ As a state of law, Indonesia has a series of regulations or laws so that the interests of the community can be protected. ${ }^{2}$ The fourth paragraph of the Preamble to the 1945 Constitution of the Republic of Indonesia, which is the constitutional basis of this country, states that one of the goals of the state is to create public welfare. So

\footnotetext{
${ }^{1}$ Anton Susanto, Ira Alia Maerani, and Maryanto, Legal Enforcement by the Police against Child of Criminal Doer of a Traffic Accident Who Caused Death (Case Study in Traffic Accident of Police Traffic Unit of Cirebon City Police Juridiction), Jurnal Daulat Hukum: Volume 3 Issue 1, March 2020, http://jurnal.unissula.ac.id/index.php/RH/article/view/8402/3928

${ }^{2}$ Asep Sunarsa, Attorney Role In Fighting Crimes Of Motorcycle Gang In Cirebon, Jurnal Daulat Hukum $\begin{array}{llllll}\text { Volume } & 1 . & \text { No. } & 2 & \text { June } & \text { 2018, }\end{array}$ http://jurnal.unissula.ac.id/index.php/RH/article/view/3291/2424
} 
all efforts and developments carried out by this country must lead to this goal so as to create people's welfare 3 .

The law is actually a reflection of the social life of a society where the law is formed. It can be said that law is a function of the social history of a society, but law is not a static social building, but it can change and this change occurs because of its function to serve the community. ${ }^{4} \mathrm{~A}$ law in society does not always act as a barrier to social change. The existence of a public attitude that cares about the law can serve as a source of extraordinary strength for the peace of the community itself.

Indonesia's National Development has a clear and directed direction and purpose, namely to achieve a just and prosperous Indonesian society, both materially and spiritually. Indonesia is a country based on law (rechtsstaat) ${ }^{5}$ namely the Indonesian state based on law (rechtsstaat) and not based on mere power (machtsstaat). The sentence has the meaning that the Republic of Indonesia is a democratic legal state, upholds human rights and guarantees that all citizens have the same position in law and government, and is obliged to uphold the law and government without exception. ${ }^{6}$ Law enforcement in a state of law such as Indonesia is important to be able to create justice in society in accordance with Indonesia's national development goals. ${ }^{7}$

The objectives of the Government of the Unitary State of the Republic of Indonesia as stated in the Preamble to the 1945 Constitution of the Republic of Indonesia, among others, are to promote general welfare and realize social justice for all Indonesian people. Therefore, the earth and the natural resources contained therein are controlled by the State and used for the greatest prosperity of the people. Roads are above, in the ground (earth), and above water, so that the right of control over the road belongs to the State as an asset that is built and maintained for traffic infrastructure, both for pedestrians and vehicles. This is also emphasized in the provisions of Article 34 paragraph (3) of the 1945 Constitution of the Republic of Indonesia which states that, "The state is responsible for the provision of health services and adequate public service facilities".

Based on Act No. 38 of 2004 concerning Roads, it is stated that the road as one of the transportation infrastructure is an important element in

the life of the nation and state, fostering the unity and integrity of the nation, and the function of society as well as in advancing the general welfare. In addition, roads play a role in realizing development goals such as equitable distribution of development and its results, economic growth, and the realization of social justice for all Indonesian people.

\footnotetext{
${ }^{3}$ A Chuasanga, Ong Argo Victoria. (2019). Legal Principles Under Criminal Law in Indonesia Dan $\begin{array}{llllll}\text { Thailand, Jurnal Daulat Hukum, Vol 2, No } 1 & \text { (2019) }\end{array}$ http://jurnal.unissula.ac.id/index.php/RH/article/view/4218

${ }^{4}$ H. Zamhari Abidin, Pengertian dan Asas Hukum Pidana, Ghalia Indonesia, Jakarta, 1996, p. 84

${ }^{5}$ Sri Praptini, Sri Kusriyah, and Aryani Witasari, Constitution and Constitutionalism of Indonesia, Jurnal Daulat Hukum: Volume 2 Issue 1, March 2019, url: http://jurnal.unissula.ac.id/index.php/RH/article/view/4149/2897 ${ }^{6}$ C.S.T. Kansil, Pengantar Ilmu Hukum dan Tata Hukum Indonesia, Jakarta : Balai Pustaka, 1989, p. 346

${ }^{7}$ Ibid, p. 56.
} 
The rapid increase in the population of big cities in various parts of the world, especially developing countries, is increasingly increasing the problem of urban mobility. Gumilar Somantri revealed that currently more than $40 \%$ of the world's population lives in urban areas, which is expected to continue to increase dramatically. ${ }^{8}$ The high population has implications for the use of limited urban resources. The imbalance between available public infrastructure and the number of people who need it causes inequality in urban services, including in the transportation sector. Inequality in the development of urban infrastructure is inseparable from the issue of development financing priorities, as stated by William Lim, "in third world countries, there is a serious scarcity of economic resources for urban infrastructure development, as there are many other priorities such as health, education, industry. , and rural development". 9

Transportation is one of the means that can be a medium for connecting people with certain destinations. Transportation provides convenience for humans in carrying out their daily activities, both in meeting the needs of life and in conducting interactions between humans. ${ }^{10}$ As for in this case, factors such as the development of the times, the increase in the human population, and the increasing economic development, and followed by the policies of two-wheeled and four-wheeled vehicle manufacturers in terms of selling vehicle units at relatively cheap prices with a Down-to-Earth system. Payment (DP) is low, resulting in the level of people's purchasing power. The impact of this policy is an increase in the number of vehicles on the highway. As a result, in the current condition, it is undeniable that traffic jams will not only affect big cities but also begin to affect traffic conditions.

Urban planning without considering the conditions and transportation patterns as a result of the planning itself will cause traffic congestion in the future which results in increased traffic congestion. ${ }^{11}$ Symptoms of this kind will arise, if there are certain factors that become obstacles, namely law makers, law enforcers, justice seekers, and other groups in society. ${ }^{12}$

From the things described above, it aims to find out and analyze the substance of traffic law products in overcoming road congestion.

\section{Research Methods}

This study uses a normative juridical approach, with an emphasis on literature study. The research specifications used are analytical descriptions. The

\footnotetext{
${ }^{8}$ Gumilar R.Somantri, Migration Within Cities: A Study of Socio-economic Processes, Intracity Migration, and Grass-roots politics in Jakarta, Lembaga Penerbit Fakultas Ekonomi Universitas Indonesia, Jakarta, 2007, p. 3

${ }^{9}$ William S.W. Lim, An Alternative Urban Strategy, Select Books PTE. LTD, Singapore, 1980, p. 62.

${ }^{10}$ Kadek Oka Suparta and Ira Alia Maerani, The Law Enforcement in Pressing Traffic Accident which Resulting Death, Jurnal Daulat Hukum: Volume 3 Issue 4, December 2020, url: http://jurnal.unissula.ac.id/index.php/RH/article/view/13144/4979

${ }^{11}$ Haryono Sukarto, Transportasi Perkotaan dan Lingkungan, Jurnal Teknik Sipil, Banten, Vol.3 No.2, Juli 2006, p. 217

${ }^{12}$ Miftah Anshori, Investigations of Corruption in Police Resort of Pati, Jurnal Daulat Hukum Volume 1. No. 2 June 2018, url:http://jurnal.unissula.ac.id/index.php/RH/article/view/3319/2450
} 
data used include secondary and tertiary data. Data analysis using qualitative descriptive.

\section{Results and Discussion}

One of the characteristics of a modern city is characterized by the availability of adequate transportation facilities and infrastructure for its citizens. In essence, there are two main factors that work as a factor in accelerating the growth and development of a city, namely the population aspect and the socioeconomic activity aspect. As a result of population growth accompanied by an increase in the economy, the level of mobility of both people and goods will also increase. This situation must be balanced with the provision of adequate transportation facilities. Thus it can be said that population growth will have a direct impact on the need for transportation facilities and infrastructure.

The transportation sector is one of the important sectors and strategies in development. In its function as a promoting sector and servicing sector, transportation has played a major role as the lifeblood of the economy. The development of this sector is intended to mobilize various regional potentials, increase the accessibility and mobility of the community, and increase the productivity of urban areas.

The growth rate of movement is very high which cannot be inhibited, while transportation facilities and infrastructure are very limited, resulting in impaired accessibility and mobility. However, regardless of the amount of costs incurred, congestion is still unavoidable, this is because the development of the provision of transportation facilities is so low that it cannot keep up and traffic jams occur. ${ }^{13}$

Traffic is defined as "pederstrians, ridding, or herded animals, vehicles stress and other conveyences either singly to together while using any highway for purposes of traffic" other means of transportation either individually or jointly using the road for its purpose. ${ }^{14}$

In everyday life, a legal activity is often carried out. Law is a system or binding rules that are officially drafted and ratified by the authorities, governments or authorities through legal institutions or institutions. An act is called a legal act, i.e. if an action has a result that can be legally accounted for. There are many examples of problems related to law violations, ranging from mild to severe, such as examples of accidents and congestion problems resulting from traffic violations. ${ }^{15}$

Traffic congestion occurs due to several factors, such as many road users who are not orderly, road users go against the flow, lack of traffic officers to supervise, the presence of cars parked on the road, uneven road surface, no pedestrian bridges, and no restrictions. The number of road users who are not orderly, such as the existence of street vendors selling on the side of the road, and

\footnotetext{
13 Hukmia, Pengaruh Aktivitas Komersial Terhadap Lalu Lintas di Koridor Jalan Perintis Kemerdekaan, Magister Perencanaan Prasarana, UNHAS, Makassar, p.80

${ }^{14}$ Djajoesman, Polisi dan Lalu Lintas, Cetakan Kedua, Jakarta, Bina Cipta, 1996, p.8

15 Alfian Jaka Prasetya, Tunggul Anshari, Lutfi Effendi, Pelaksanaan Peraturan Walikota Malang No.35 Tahun 2013 tentang Rekayasa Lalu Lintas di Kawasan Jalan Sumberasih-Jalan Gajayana-Jalan MT.Haryono-Jalan D.I.Panjaitan-Jalan Bogor Dalam Mengurai Kemacetan, FH Unbraw, 2014, p.3
} 
illegal parking. In addition, there are road users who go against the flow. This happens because of the lack of traffic officers in dealing with traffic, especially on roads that are prone to traffic jams. ${ }^{16}$

Traffic can be used as a benchmark for the progress of an area or city that has a high traffic volume. Regular traffic can show that the traffic discipline of the population is also high, so it can be said that development in the area is developing well. As the population's economy increases, the ability to own a private vehicle also increases, resulting in traffic congestion in a city with a high population density. Thus congestion and traffic violations also increase. ${ }^{17}$

The state's efforts in the form of legislation with the existence of legal products that are correlated to overcoming the problem of congestion on the highway with various concepts of interrelated substances include:

\subsection{Act No. 22 of 2009 concerning Road Traffic and Transportation}

In the context of the implementation of road traffic and transportation, Act No. 22 of 2009 concerning Road Traffic and Transportation (hereinafter abbreviated as Law on LLAJ) has been established which regulates several provisions, including those related to the objectives of road traffic and transportation. , division of authority between government agencies and regional governments, regulation of technical matters of road traffic and transportation operations, road traffic and transportation infrastructure, as well as efforts to foster, prevent, regulate, and enforce law.

In practice, the Law on LLAJ is still unable to accommodate developments, problems, and legal needs in the community. Changes that occur in society in the context of road traffic and transportation occur so quickly beyond the existing provisions of the Law on LLAJ. These changes should be followed by changes to the existing legal rules so that conditions in society can be accommodated by law. In legal science, this concept is known as formal legal politics which aims to make the ius constitutum which was developed from the old legal systems, into ius constituendum or law for the future. ${ }^{18}$

\subsection{Act No. 23 of 2014 concerning Regional Government (Law on Regional Government)}

Article 9 paragraph (1) of Act No. 23 of 2014 concerning Regional Government (hereinafter referred to as the Regional Government Law) states that there are 3 (three) types of government affairs, namely absolute government affairs, concurrent government affairs, and general government affairs. Government affairs under the authority of the Regions consist of Mandatory Government Affairs and Preferred Government Affairs. Basically Traffic is included in the mandatory government affairs related to transportation as regulated in Article 12 paragraph (2) letter I of the Regional Government Law.

\footnotetext{
16 W. Boediningsih, Dampak Kepadatan Lalu Lintas terhadap Polusi Udara Kota Surabaya, Surabaya, Universitas Narotama Surabaya, 2011, p.28

${ }_{17}$ Alfian Jaka Prasetya, Tunggul Anshari, Lutfi Effendi, Op.Cit, 2014, p.4

${ }^{18}$ F. Sugeng Istanto, Abdul Latif dan Hasbi Ali, Politik Hukum, Jakarta: Sinar Grafika, 2010, p.6
} 
Regulations regarding Traffic are contained in the Appendix to the Regional Government Law. In the division of government affairs in the field of transportation, the sub-affairs of Traffic and Road Transportation are divided into the authority of traffic and road transportation between the central government, provincial regional governments, and district/city regional governments.

\subsection{Act No. 38 of 2004 concerning Roads (Law on Roads)}

The Law on Roads regulates roads as land transportation infrastructure which includes all parts of the road, including complementary buildings and equipment intended for traffic, which are on the ground surface, above the ground surface, below the ground and/or water surface, as well as in the ground above the water surface, except for railways, lorry roads, and cable roads as defined by the Road in Article 1 point 4 of the Law. ${ }^{19}$

So in this case there is a very close relationship between roads as infrastructure and traffic spaces that utilize parts of the road for the movement of people and goods. Article 10 of the Law on Roads states that in order to regulate road use and smooth traffic, roads are divided into several road classes. ${ }^{20}$ The division of road classes is regulated in accordance with the provisions of laws and regulations in the field of road traffic and transportation, namely the Law on LLAJ. The arrangement of road classes based on the specifications for the provision of road infrastructure is grouped into expressways, highways, medium roads, and small roads. Class arrangement and specifications for the provision of road infrastructure are of course influenced by traffic that will utilize the road space.

4. Government Regulation Number 32 of 2011 concerning Management and Engineering, Impact Analysis, and Traffic Needs Management

PP Management and Engineering, Impact Analysis, and Traffic Demand Management focuses on traffic demand management which is implemented with the aim of increasing the efficiency and effectiveness of the use of traffic space and controlling traffic movement. ${ }^{21}$ The implementation of traffic demand management in this case becomes a reference in overcoming congestion on the highway carried out by:

- Methods of restricting individual vehicle traffic in certain corridors or areas at a certain time include restrictions on goods vehicle traffic, motorcycle traffic restrictions (Articles 64-71);

- Restriction of parking space in certain areas with a maximum parking space limit (Article 72-75); and/or

- Restrictions on general non-motorized vehicle traffic (Articles 76-78).

Thus, technical arrangements regarding the implementation of traffic management and engineering must pay attention to the regulations of PP on Management and Engineering, Impact Analysis, and Management of Traffic Needs.

\footnotetext{
${ }^{19}$ Article 1 number 5 of Act No. 38 of 2004 concerning Roads

20 Article 10 of Act No. 38 of 2004 concerning Roads

${ }^{21}$ Government Regulation Number 32 of 2011 concerning Management and Engineering, Impact Analysis, and Management of Traffic Needs (PP Management and Engineering, Impact Analysis, and Traffic Needs Management).
} 
In the event that there is a change in the Law on LLAJ, the PP on Management and Engineering, Impact Analysis, and Management of Traffic Needs must adjust to the substance of the change.

\section{Closing}

The state's efforts in the form of legislation with the existence of legal products that are correlated to overcoming the problem of congestion on the highway with various concepts of interrelated substances, including Act No. 22 of 2009, concerning road traffic and transportation have a strategic role in supporting development, national integration as a efforts to promote public welfare, traffic and road transportation services that are safe, safe, orderly, smooth, integrated. Act No. 23 of 2014 concerning Regional Government in Article 9 paragraph (1) states that there are 3 (three) types of government affairs, namely absolute government affairs, concurrent government affairs, and general government affairs. Government affairs under the authority of the Regions consist of Mandatory Government Affairs and Preferred Government Affairs. Article 10 of Act No. 38 of 2004 concerning Roads states that to regulate road use and smooth traffic, roads are divided into several road classes. Government Regulation Number 32 of 2011 concerning Management and Engineering, Impact Analysis, and Traffic Needs Management, the scope of regulation of PP Management and Engineering, Impact Analysis, and Traffic Needs Management includes traffic management and engineering activities including planning, regulation, engineering, empowerment, and supervision. Planning, regulation, engineering, empowerment and supervision activities are carried out by the minister who is responsible for the field of traffic facilities and infrastructure and road transportation for the national road, the minister who is responsible for the road sector for the national road,

\section{References}

\section{Journals}

[1] Alfian Jaka Prasetya, Tunggul Anshari, Lutfi Effendi, Pelaksanaan Peraturan Walikota Malang No.35 Tahun 2013 tentang Rekayasa Lalu Lintas di Kawasan Jalan Sumberasih-Jalan Gajayana-Jalan MT.Haryono-Jalan D.I.Panjaitan-Jalan Bogor Dalam Mengurai Kemacetan, FH Unbraw, 2014

[2] Anton Susanto, Ira Alia Maerani, and Maryanto, Legal Enforcement by the Police against Child of Criminal Doer of a Traffic Accident Who Caused Death (Case Study in Traffic Accident of Police Traffic Unit of Cirebon City Police Juridiction), Jurnal Daulat Hukum: Volume 3 Issue 1, March 2020, http://jurnal.unissula.ac.id/index.php/RH/article/view/8402/3928

[3] Asep Sunarsa, Attorney Role In Fighting Crimes Of Motorcycle Gang In Cirebon, Jurnal Daulat Hukum Volume 1. No. 2 June 2018, url: http://jurnal.unissula.ac.id/index.php/RH/article/view/3291/2424

[4] Haryono Sukarto, Transportasi Perkotaan dan Lingkungan, Jurnal Teknik Sipil, Banten, Vol.3 No.2, Juli 2006

[5] Kadek Oka Suparta and Ira Alia Maerani, The Law Enforcement in Pressing Traffic Accident which Resulting Death, Jurnal Daulat Hukum: Volume 3 Issue 
4

December

2020

url:

http://jurnal.unissula.ac.id/index.php/RH/article/view/13144/4979

[6] Miftah Anshori, Investigations of Corruption in Police Resort of Pati, Jurnal Daulat Hukum Volume 1. No. 2 June 2018, url:http://jurnal.unissula.ac.id/index.php/RH/article/view/3319/2450

[7] Sri Praptini, Sri Kusriyah, and Aryani Witasari, Constitution and Constitutionalism of Indonesia, Jurnal Daulat Hukum: Volume 2 Issue 1, March 2019, url: http://jurnal.unissula.ac.id/index.php/RH/article/view/4149/2897

\section{Books}

[1] C.S.T. Kansil, 1989, Pengantar Ilmu Hukum dan Tata Hukum Indonesia, Jakarta: Balai Pustaka

[2] Djajoesman, 1996, Polisi dan Lalu Lintas, Cetakan Kedua, Jakarta, Bina Cipta

[3] F. Sugeng Istanto, 2010, Abdul Latif dan Hasbi Ali, Politik Hukum, Jakarta: Sinar Grafika

[4] Gumilar R.Somantri, 2007, Migration Within Cities: A Study of Socio-economic Processes, Intracity Migration, and Grass-roots politics in Jakarta, Lembaga Penerbit Fakultas Ekonomi Universitas Indonesia, Jakarta

[5] Hukmia, Pengaruh Aktivitas Komersial Terhadap Lalu Lintas di Koridor Jalan Perintis Kemerdekaan, Magister Perencanaan Prasarana, UNHAS, Makassar

[6] H. Zamhari Abidin, 1996, Pengertian dan Asas Hukum Pidana, Ghalia Indonesia, Jakarta

[7] W. Boediningsih, 2011, Dampak Kepadatan Lalu Lintas terhadap Polusi Udara Kota Surabaya, Surabaya, Universitas Narotama Surabaya

[8] William S.W. Lim, 1980, An Alternative Urban Strategy, Select Books PTE. LTD, Singapore 